\title{
Disentangling the effects of household financial constraints and risk profile on mortgage rates
}

Carbo-Valverde, Santiago; Mayordomo, Sergio; Rodríguez-Fernández, Francisco

\section{The Journal of Real Estate Finance and Economics}

DOI:

$10.1007 / \mathrm{s} 11146-016-9595-7$

Published: 01/01/2018

Peer reviewed version

Cyswllt i'r cyhoeddiad / Link to publication

Dyfyniad o'r fersiwn a gyhoeddwyd / Citation for published version (APA):

Carbo-Valverde, S., Mayordomo, S., \& Rodríguez-Fernández, F. (2018). Disentangling the effects of household financial constraints and risk profile on mortgage rates. The Journal of Real Estate Finance and Economics, 56(1), 76-100. https://doi.org/10.1007/s11146-016-9595-7

\footnotetext{
Hawliau Cyffredinol / General rights

Copyright and moral rights for the publications made accessible in the public portal are retained by the authors and/or other copyright owners and it is a condition of accessing publications that users recognise and abide by the legal requirements associated with these rights.

- Users may download and print one copy of any publication from the public portal for the purpose of private study or research.

- You may not further distribute the material or use it for any profit-making activity or commercial gain

- You may freely distribute the URL identifying the publication in the public portal ?
}

Take down policy

If you believe that this document breaches copyright please contact us providing details, and we will remove access to the work immediately and investigate your claim. 


\title{
Disentangling the effects of household financial constraints and risk profile on mortgage rates
}

\author{
Santiago Carbó-Valverde \\ Bangor Business School and Funcas \\ (s.carbo-valverde@bangor.ac.uk) \\ Sergio Mayordomo* \\ Banco de España \\ (sergio.mayordomo@bde.es) \\ Francisco Rodríguez-Fernández \\ University of Granada and Funcas \\ (franrod@ugr.es)
}

*Corresponding author: Sergio Mayordomo, DG Economics and Statistics, Banco de España, C/ Alcalá, 28014 Madrid, Spain; e-mail: sergio.mayordomo@bde.es; phone: +34 917088149. Carbó and Rodríguez-Fernández acknowledge financial support from the Funcas Foundation. The views expressed in this paper are those of the authors and do not necessarily coincide with those of the Banco de España and the Eurosystem. 


\title{
Disentangling the effects of household financial constraints and risk profile on mortgage rates
}

\begin{abstract}
In this paper we disentangle the impact of household financial constraints on mortgage rate from a number of dimensions of credit risk. This analysis relies on a dataset that contains information on the economic and financial decisions of Spanish households in four different years: 2002, 2005, 2008, and 2011. Our results suggest that banks' profitable customers are able to bargain for lower mortgage rates. However, contrary to other studies, the risk profile does not have a significant effect on mortgage rates. Credit institutions tend to charge higher rates during the crisis to all customers, irrespective of their risk profiles.
\end{abstract}

JEL classification: G21, R21

Keywords: Households, mortgages, financial constraints, credit risk 


\section{Introduction}

We analyze credit institutions' mortgage rate lending policy to households, disentangling the impact of financial constraints from that of the borrower's risk profile. In particular, we study how the mortgage rates charged to households depend on their credit risk, the constraints they face, and their characteristics as profitable bank customers. This analysis relies on a dataset that contains information on the economic and financial decisions of Spanish households in four different survey waves conducted in 2002, 2005, 2008 and 2011. Having information on such years facilitates a better understanding of the business cycle and the recent financial crisis in the aforementioned analyses.

The focus on the conditions of household credit relies on the high relevance of this type of credit for both banks and households. Thus, Beck et al. (2012) document that over the period 1994 - 2005 household credit amounted to $80 \%$ of bank credit in Canada, $76 \%$ in the United States (U.S.), 66\% in Australia, 60\% in France and 56\% in the United Kingdom. Mortgages are also the most important financial liabilities of households, accounting for $75 \%$ of household debt in the U.S. (Bucks et al. 2009) and $83 \%$ in the Eurozone (European Central Bank 2013).

There is extensive literature analyzing the effect that the financial constraints households face when looking for external funding has on the homeownership rate. The general result is that both income and wealth constraints affect the homeownership rate (see Linneman and Wachter 1989; Duca and Rosenthal 1994a; Linneman et al. 1997; Haurin et al. 1996, 1997; Rosenthal 2002; Barakova et al. 2003; Calem et al. 2010; among others for evidence based on U.S. households, or Bourassa and Hoesli 2010 for evidence based on Swiss households). Wealth constraints have been found to dominate income constraints in the U.S. (Barakova et al. 2014), Europe (Ampudia and Mayordomo 2015), 
and Italy (Diaz-Serrano 2005). Thus, credit constraints should affect borrowing rates as they affect the decision to buy/rent a home. Contrary to previous papers, our interest does not rely on the effect of financial constraints on access to housing but on the cost of that funding.

The effect of financial constraints on mortgage rates has been indirectly studied through household risk or credit scoring. Based on U.S. data, Einav et al. (2013) show that one of the advantages of the better risk classification of credit scoring is the ability of lending institutions to target more generous loans at lower-risk borrowers. Edelberg (2006) shows that lenders used risk-based pricing of interest rates in consumer loan markets in the U.S. during the mid-1990s. Along the same line, Magri and Pico (2011) analyze the mortgage pricing of Italian households between 2000 and 2007 to show that lenders have increasingly priced mortgage interest rates on household credit risk. Chiang et al. (2002) employ data from Hong Kong to document that households with the worst credit scoring are charged a higher mortgage rate spread. Tsai et al.'s (2009) model reaches a similar conclusion as default risk increases the mortgage yield. On the contrary, Duca and Rosenthal (1994b) provide little support for the hypothesis that U.S. lenders vary mortgage rates across loan applicants on the basis of observable differences in credit risk. Thus, lenders may respond to the borrower risk by varying non-rate terms such as the down-payment or payment-to-income constraints.

There is no consensus on the relationship between credit scoring and mortgage rates. In addition, the effect of financial constraints on mortgage rates has not been studied directly, but indirectly through household risk or credit scoring. Our paper aims to provide additional evidence to this discussion, analyzing the effect that household credit scoring or credit risk and financial constraints have on mortgage rates Moreover, our paper also 
contributes to the literature by analyzing the evolution of lending standards in the context of the recent crisis.

Beyond the household risk profiles and the conditions for access to funding, not much is known about the effect of other dimensions that could be of interest to banks' business lines, such as the future profitability of customers. The analysis of the effect of financial characteristics of banks' customers is related to the financial intermediation literature, which documents that relationship banking mitigates information asymmetries between lenders and borrowers. In line with this 'information view' of relationship banking, extensive empirical literature explores the prevalence and economic relevance of firm-bank relationships in corporate lending. Recent studies also show the role of relationship banking in consumer credit in the U.S. (Holmes et al. 2007, Agarwal et al. 2010) and Germany (Puri et al. 2011) and mortgages in U.S. (Keys et al. 2010) and Switzerland (Brown and Hoffmann 2013). Keys et al. (2010) were the first to show evidence on the role of information asymmetries between lenders and borrowers in mortgage lending during the recent financial crisis. Brown and Hoffmann (2013) contribute to this strand of literature by providing empirical evidence on the scope, geographic proximity and duration of mortgage relationships, and by examining whether the heterogeneity of mortgage relationships across households can be rationalized by information asymmetries between lenders and borrowers. Finally, Allen et al. (2014) use transaction-level data on Canadian mortgage contracts to document the existence of price discrimination by banks that is explained by consumer bargaining leverage.

We share some of the objectives pursued by previous papers as several of the household dimensions used to characterize them as profitable customers for the bank can also be used to define household-bank relationship. Nevertheless, our paper analyzes in detail the former theory and presents an exhaustive study that divides the customer 
profitability dimension into two categories depending on the banking business to which they refer: asset management or fee-oriented activities.

By way of a preview, the main findings of the paper are as follows: those households who may become profitable customers are able to bargain for lower mortgage rates. Nevertheless, household credit risk is not a driver of mortgage rates as credit institutions charge similar rates irrespective of the household risk profile before and during the crisis. In fact, credit institutions tend to charge higher rates during the crisis to all customers irrespective of their risk profiles or their degree of profitability. This result suggests that instead of household idiosyncratic risk, borrowing rates could be affected by a factor reflecting aggregate level of risk common to all households. In addition the level of households' credit risk could be an important driver of the bank's decision on whether or not to grant the mortgage. In this sense, in Spain it has been common for banks to advertise a mortgage rate that it is supposed to reflect the aggregate level of risk and represents the maximum level of a spread over a market index. This adjustable rate can be modified downwards if customers meet a number of requirements, including having other services already provided by the same bank (e.g. insurance, savings accounts or direct debits). Hence, the credit scoring of banks in Spain frequently evaluates whether customers are eligible for such a mortgage contract at the advertised rate, only subsequently, if the customers qualifies for a lower rate because they satisfy certain crossselling conditions and have an appropriate level of wealth. During upturns, and in particular during a housing bubble, bank competition pushes some of these adjustable rates excessively downwards and banks incur an excessive long-term risk as the rates do not reflect the over-the-cycle risk profile of borrowers but rather their current wealth status and the scope (number of services) of their relationship with the bank. 
The paper is structured as follows. Section 2 describes the data, hypotheses and methodology. Section 3 contains the results and Section 4 some robustness tests. Section 5 concludes.

\section{Data, hypotheses and methodology}

\subsection{Data sources}

The data employed for this study originate from the Spanish Survey of Household Finances (Encuesta Financiera de las Familias, EFF hereafter), managed by the Bank of Spain. This survey gathered data about the financial and economic situation of Spanish households in 2002, 2005, 2008, and 2011. The survey also includes detailed information on their assets, liabilities, sources of income, use of financial services, demographic characteristics and housing. The EFF offers certain retrospective information on housing, such as the year and price of acquisition, and the amount and conditions relating to the mortgage at both the origination and the survey date, if the mortgage is still in existence. The information in this survey will also enable us to obtain information on the financial status of households (wealth and income constraints). Additionally, as mentioned above, it is possible to obtain information on the mortgage at the survey date and when the housing was purchased. The data availability (from 2002 to 2011) facilitates the analysis of the research hypotheses -defined in the next section- under both pre-crisis and crisis periods.

Among the determinants of mortgage rates considered in our analysis are the financial constraints faced by households on lending conditions. In order to deal with the effect of these constraints we need to implement a two-fold analysis so that we first predict the coefficients for the desired home value to construct credit constraints. Then, we evaluate the lending conditions based on household characteristics such as the 
financial constraints they face, their risk, and their nature as potential profitable customers for banks.

The subsamples originating from the original data for the analysis devoted to estimating the desired housing value is defined following the method of Ampudia and Mayordomo (2015) in their study of the role of financial constraints on homeownership. The subsample selects the homeowners in which the person of reference is between 25 and 60 years old in the year of the survey. We exclude those households who received the home free of charge or in the form of a bequest. Some of the households in the EFF appear in several waves and some of them appear just once. We select those households who have been living in their current primary residence for 3 years or less, so that the retrospective imputation of income, wealth, and other demographic characteristics is more reliable. The use of recent homeowners implies that both the purchase value and the value on the survey date, as declared by the household, are a proper approximation for the real purchase price and the real current price, respectively. Due to discrepancies in the survey years and the year in which the households purchased the home, we use retrospective imputation methods to use the information accordingly. For instance, to know the income we use the inflation rate to adjust the current income; as regards the wealth, we consider consumption, income, and debt payments.

The sample used to analyze the determinants of the mortgage rates is defined from the same households used to obtain their desired housing value who are living in an owned property and who financed their house purchase through a loan.

The EFF makes imputations to correct answers of the type "do not know, do not answer" and offers five imputed values. The multiple interaction allows us to reflect the uncertainty associated with the imputation process (see Rubin (1987)) and is relevant to 
estimating the parameters of a regression and to constructing the descriptive statistics, especially those related to the income and wealth dispersion. ${ }^{1}$

\subsection{Research Hypotheses}

Before the recent financial crisis, credit supply was high and it diminished substantially during the crisis. Nevertheless, little is known about the dimensions that the banks considered when setting the price of such mortgages. Customers identified as profitable for the bank exhibit a higher bargaining power to negotiate interest rates. Among the dimensions that define profitable customers are the use of credit cards, electronic payments, checks, direct billing or direct deposits, telephone banking and Internet banking. ${ }^{2}$

Hypothesis 1: Households offering potential profit opportunities to the bank benefit from mortgages with lower interest rates.

However, there could be other household characteristics that would increase the interest rate charged to the mortgage. Among these characteristics we highlight the ones related to the household's risk profile: credit scoring, previous indebtedness and financial constraints.

\footnotetext{
1 In addition, households have different likelihoods of being selected for the survey, given the overrepresentation of the wealthiest households and the geographic stratification. For this reason, the survey contains weights for each household that are necessary in order to obtain descriptive statistics for the population. Nevertheless, following Rosenthal (2002), to estimate the models proposed in this study we assign the same weights to each observation of the corresponding subsample.

${ }^{2}$ The customer profitability measures in our study cannot directly capture the extent to which those profits come from cross-selling opportunities. However, we hypothesize that this cross-selling to customers represents potential profitable opportunities for the bank. In fact, it is very common in Spain for the bank granting the mortgage to typically offer interest rate discounts (or other benefits associated with the mortgage) to their already existing or new customers if these clients already hold or purchase other (feeoriented) products from the bank (i.e., credit and debit cards, saving accounts, pension funds, mutual funds, insurances,...).
} 
Hypothesis 2: Financial institutions charge higher rates to those households being financially constrained, with poor credit scoring, and with a portfolio of debt prior to purchasing the house.

Credit institutions could have changed their lending standards during the recent crisis. For this reason, we check the validity of the aforementioned hypotheses during the crisis period. During the crisis, there could be price dispersion such that higher interest rates could have been charged to constrained and indebted households or, on the contrary, banks could charge higher mortgage rates without considering households' characteristics.

Hypothesis 3: Credit institutions tend to charge higher rates during the crisis to all customers irrespective of their risk profiles or their degree of profitability.

\subsection{Methodology}

The methodology consists of two stages. In the first, we estimate the desired home value to define the financial constraints faced by households; this variable will be employed jointly with other potential drivers of lending conditions to understand the banks' lending practices.

\subsubsection{Estimation of desired home value}

The estimation of a desired home value could be problematic as the distance between the survey and the purchase dates expands. For this reason, we employ a subsample of households consisting of those buying their home during the period spanning the three years prior to the survey date (for each of the four EFF surveys). For this purpose we use the home purchase price to define the desired home value for those households that are not constrained. To implement this analysis, the explanatory variables need to be 
specified for the same year in which the housing was purchased, given that the desired housing value is determined from the housing purchase price. However, the values for the explanatory variables in the survey correspond to the year when the household was interviewed rather than the year when the housing was purchased. Consequently, we apply discount factors to express the explanatory variables in terms of the year of the purchase. This methodology is explained in detail in the Appendix.

We first define the wealth and income constraints faced by the EFF households at the home purchase date from the desired home and purchase limit values compatible with the household not being constrained in wealth and income. For the case of wealth, we define the limit value compatible with not being constrained in wealth as:

$$
V_{i}^{W}=\frac{N W_{i}}{1-0.8}
$$

where $N W_{i}$ is the household net wealth at the home purchase year and 0.8 is the maximum loan-to-value compatible with banks' standard provisions. This constraint requires refraining from lending the whole value of the house to avoid moral hazard problems and ensure incentive compatibility.

We next define the purchase limit value compatible with the household not being constrained in income as:

$$
V_{i}^{Y}=\frac{0.33 Y_{i}}{r 0.8}
$$

where $Y_{i}$ denotes the total annual household income at the home purchase year and $r$ is the interest rate that is applied to the loans for the home purchase. ${ }^{3}$ This constraint requires

\footnotetext{
${ }^{3}$ Interest rates are obtained from the European Central Bank statistics on the monetary financial institution (MFI) sector.
} 
the mortgage payments to be less than $33 \%$ of household income (the loan payment is interest only). This constraint ensures that the household is able to pay the mortgage and avoid potential high delinquency ratios. In the access-to-mortgage guide elaborated by the Central Bank of Spain, ${ }^{4}$ one of the variables that is explicitly considered to determine the amount of the loan is household income. This guide explicitly recognizes that an important aspect is the borrower's payment capacity, given that both lender and borrower should try to ensure that their monthly mortgage payment does not exceed a given percentage of their monthly net income. This is to guarantee that once the mortgage payment is made, the household has a level of income high enough to afford the standard expenditure. Among the mortgage recommendations given to banks and households is the limit that the mortgage payment should represent over the household net income. In particular, the monthly mortgage payment should not exceed $30-35 \%$ of households' monthly income..$^{5}$

In the event that the desired home value of household $i$ on the date at which it purchased its current home, $V_{i}^{*}$, is greater than $V_{i}^{W}$, the household is constrained in wealth. Equivalently, the household is constrained in income if $V_{i}^{*}$ is greater than $V_{i}^{Y}$.

To implement the corresponding estimation, a household is considered as constrained, irrespective of whether it is constrained in income or wealth, if the logarithm of the desired home value is greater than the logarithm of the minimum of the two limit values, $V_{i}^{W}$ and $V_{i}^{Y}$, which for notational simplicity is redefined as $Z_{i}=$ $\min \left[\frac{\mathrm{NW}_{\mathrm{i}}}{1-0.8}, \frac{0.33 \mathrm{Y}_{\mathrm{i}}}{\mathrm{r} 0.8}\right]$.

\footnotetext{
${ }^{4}$ See "Guía de Acceso al Préstamo Hipotecario" (Bank of Spain): http://www.bde.es/bde/es/secciones/informes/Folletos/guia_de_acceso_a/

${ }^{5}$ See the webpage on financial education developed by the Central Bank of Spain and the Securities and Exchange Commission (Finanzas para Todos):

http://www.finanzasparatodos.es/es/economiavida/comprandovivienda/compraroalquilar.html
} 
We then apply a censored model where the censored variable, $\ln \overline{\mathrm{V}}_{\mathrm{i}}$, is modelled as:

$$
\ln \bar{V}_{i}=\left\{\begin{array}{cl}
\ln V_{i}^{*} & \text { if } \ln V_{i}^{*}<\ln Z_{i} \\
\ln Z_{i} & \text { otherwise }
\end{array}\right.
$$

where all the variables are observable with the exception of $V_{i}^{*}$ in case $\ln V_{i}^{*} \geq \ln Z_{i}$. When $\ln V_{\mathrm{i}}^{*}<\ln \mathrm{Z}_{\mathrm{i}}$ the desired housing value $\mathrm{V}_{\mathrm{i}}^{*}$ is the home purchase price for the house in which household $i$ lives. It is postulated that $\ln _{\mathrm{i}}^{*}$ will be given by:

$$
\ln V_{i}^{*}=\beta^{\prime} X_{i}+u_{i}
$$

where $\mathrm{u}_{\mathrm{i}} \mathrm{iid} \sim \mathrm{N}\left(0, \sigma^{2}\right)$ and $X_{i}$ is a vector containing the household characteristics at the year in which the households purchased the house: the logarithm of annual income, the logarithm of gross wealth, age of the person of reference and its square. Moreover, $\mathrm{X}_{\mathrm{i}}$ contains other current characteristics of the household that are assumed to be invariant between the date the home is purchased and the survey date (marital status, gender, labor situation, education, whether the household lives in an urban or rural area, number of household members, and the number of those members that are employed), and the year the home was purchased, to control by the specific characteristics of each year. $\beta$ is the vector of coefficients accompanying the variables in vector $\mathrm{X}_{\mathrm{i}}$. The specification given by equations (3) and (4) corresponds to a generalized Tobit model (given that the point of censure $\mathrm{Z}_{\mathrm{i}}$ varies across individuals) that will be estimated by maximum likelihood.

\subsubsection{The role of households' risk profiles and characteristics on mortgage rates}

The desired home value at the year of the survey, $\widehat{V}_{i}^{*}$, is obtained from the estimated coefficients in the previous stage. This imputation is done for each of the households in the sample using the value of the variables for the year in which they moved to their 
current home. The sample consists of households who are living in an owned house and financed their purchase of the house through a loan. We denote the new limit values compatible with the household not being constrained in income and wealth as $V_{i}^{Y^{\prime}}$ and $V_{i}^{W^{\prime}}$, respectively.

To have a continuous indicator to measure the strength of financial constraints, we use as a proxy for financial constraints the ratio of the desired home value relative to each of the limit values of the two constraints. Thus, we measure the degree of constraint in wealth and income as $\frac{\widehat{V}_{i}^{*}}{V_{i}^{W^{\prime}}}$ and $\frac{\widehat{V}_{i}^{*}}{V_{i}^{Y^{\prime}}}$, respectively. In the event that either of the two previous ratios are greater than 1, that household will be constrained and the higher the ratio, the stronger the degree of constraint.

Besides financial constraints, we use a credit risk indicator as an additional dimension of household risk profile. As shown in the Appendix, the credit scoring is also based on income and wealth information. In order to disentangle the effect of both financial constraints and the indicator of credit risk we orthogonalize the two credit constraint variables by regressing them on the credit risk indicators and using the residuals to proxy for the income and wealth constraints. After defining the constraints, we estimate the effect of a series of variables affecting bank lending policies through the interest rates charged to the mortgages. For that aim, we regress the mortgage interest rate in excess of 1-year Euribor for household $i\left(r_{i}\right)$ on a vector of variables $X_{i}$ affecting the mortgage rate:

$$
r_{i}=\delta^{\prime} Z_{i}+\varepsilon_{i}
$$

where the vector $Z_{i}$ includes a measure of the household risk scoring; a variable indicating whether the household is profitable for the bank in view of its use of banking resources; the orthogonalized wealth and income constraints; a dummy variable indicating whether 
the household has other types of debt besides the mortgage; and the age and labor situation of the person of reference. Furthermore, we use dummy variables indicating the year the home was purchased in order to control by the specific characteristics of each year.

\section{Results}

\subsection{Estimating the desired home value}

Panel A of Table 1 contains the descriptive statistics of several variables employed to estimate the desired housing value. ${ }^{6}$ The sample is built from homeowners and consists of a total of 864 households. The appendix includes the definition of all the variables of interest employed in the estimation of the desired home value.

< Insert Table 1 here >

The coefficients concerning the effect of the variables on the home purchase price, according to the Tobit model, for estimating the desired home value are reported in Table 2. The sample consists of 864 households who purchased their homes between 1999 and 2011. Of those households, 175 are censored.

We observe that both the annual income and the gross wealth before the home purchase exhibit a positive and significant effect on the desired home value. In regard to household demographic characteristics such as age, gender, number of people living in the home, or marital status, we do not observe any significant contribution to the desired home value after controlling by means of the other characteristics employed in this analysis. On the other hand, the well-educated tend to prefer more expensive houses than those households that only completed primary education. We observe that the higher the number of employed people living in the home, the lower the desired home value. This

\footnotetext{
${ }^{6}$ The standard deviations of dummy variables are not reported as they are meaningless.
} 
effect could be explained by the fact that lower income/wealth tends to increase the number of household members working, to achieve a minimum level of income/wealth. As regards the labor situation, the dummy variable that is employed as a reference in order to interpret the coefficients refers to households that are employed (not selfemployed). We then observe that the only employment category leading to significant differences in terms of the desired home value is the one relating to retired households. The desired home value of retired households is much lower than the value observed for households in which the person of reference is employed. We observe that the desired value for houses in urban areas is substantially higher than in rural areas. These coefficients will be used to impute the household's desired home value in the next part of the analysis.

< Insert Table 2 here >

\subsection{The role of households' risk profiles and characteristics on mortgage rates}

The sample employed to study the determinants of mortgage rates consists of 636 households and the descriptive statistics for the variables employed in the corresponding analysis are contained in Panel B of Table 1. We observe that the average spread over 1year Euribor for those households with a mortgage is 134 basis points. Average customer profitability is 2.99 , indicating that, on average, households use/hold three types of the services/assets offered by the bank. The vast majority of these services are fee-oriented. Regarding the degree of income constraints, we observe that the desired home value in terms of income and wealth limits is lower than one, indicating that the average household is neither income nor wealth constrained. However, the average household tends to be more frequently wealth than income constrained. Finally, we observe that $38 \%$ of 
households have other types of debt rather than the mortgage employed to purchase the home.

Table 3 contains the results for the estimation of equation (5). The total number of homeowners with mortgage in this analysis consists of 636 households. The interest rates are mainly determined by macro/global conditions due to the high significance of the year dummy variables. Besides these macro effects, we observe that the main channel to bargaining on interest rates is being a potentially profitable customer for the bank (in line with Hypothesis 1). The results point towards a negligible effect of variables relating to household risk profile on the interest rate that is later charged to the household, which does not support Hypothesis 2. Nevertheless, we observe that unemployed households pay higher mortgage rates.

\section{< Insert Table 3 here >}

The high level of competition in the Spanish mortgage market could explain why mortgage rates do not differ across borrowers. A number of studies such as van Leuvensteijn et al. (2011) or Crespi et al. (2004) show evidence of this intense competition in Spain, both for commercial and saving banks. The deregulation and liberalization of the banking sector in Spain in the early 1990s helped to explain this phenomenon. During the first years of our sample period, the saving banks extended their branches out of their original regions. This led to a significant increase in the number of branches per capita. In fact, according to The World Bank Data, Spain was the second country with the highest number of commercial bank branches per 100,000 adults in 2008 and 2011 after San Marino. There were 88.54 branches per 100,000 adults in 2011 and 104.01 in 2008 . This is a very high number compared to the European Union (34 and 33 
branches on average in 2008 and 2011, respectively) in which a high percentage of residential mortgages are originated by banks.

The effect of this high competition could particularly affect the mortgage market. Lago-González and Salas-Fumás (2005) document that mortgages have shown a low degree of differentiation in Spain. Similarly, Maudos et al. (2002) indicate that there was downward pressure on interest margins in Spain in the 1990s due to competition, inter alia, in mortgage markets. Therefore, the borrower risk could be incorporated in the bank decision to grant loans given that the high level of competition impedes banks from adapting mortgage interest rates to borrower risk.

Being a profitable customer for financial institutions includes several dimensions that could be dealt with in detail. Thus, banks may consider such customers to be profitable because they have a wide battery of financial assets that can be managed by the banking group, such as mutual funds, pension funds or insurance. In addition, households may be of interest to banks due to the use of other services offered by the bank, such as credit cards, checks, direct billing, telephone and internet banking, or electronic payments that represent income for financial institutions. Thus, we split the customer profitability variable into two categories according to the banking business to which they refer: asset management or fee-oriented activities. Column 2 of Table 3 shows the results obtained when the two customer profitability related variables are jointly introduced in the regression. We observe that although both types of activities exhibit a negative coefficient, only those customers who are of interest to the bank due to fee-oriented activities benefit from significantly lower mortgage rates. In fact the coefficient associated to fee-oriented activities is statistically significantly higher than the one related to asset management activities. For an additional comparison of the coefficients, we analyze the effect of each explanatory variable on the dependent variable given a change 
of one standard deviation on the former variables. Thus, when the variable showing feeoriented activities increases by one standard deviation (0.98), the mortgage rate charged decreases by 14.4 b.p. Nevertheless, when the variable reflecting to asset management activities increases by one standard deviation (0.65), the mortgage rate charged only decreases by 3.2 b.p.

Finally, due to the characteristics of our data, which include a pre-crisis and a crisis period, we analyze the differential effects of the previous variables reflecting different banking practices during the crisis period. For this purpose, we repeat the previous analysis and include a series of additional explanatory variables in both stages. These additional variables consist of a dummy variable for the crisis period that takes on a value of 1 after 2009 (the year after the Lehman Brothers' collapse at the end of 2008) and the interaction of this dummy variable with the four variables relating to household risk profile (orthogonalized income and wealth constraints, risk scoring, and use of other types of debt) and with the variables relating to customer profitability. Results are reported in Table 4.

We obtain a non-significant effect for the wealth constraint and the credit risk indicator that provides suggestive evidence of a strong monitoring of wealth constraints and risk with regard to access to funding, rather than charging higher rates to those constrained households. In fact, the only crisis related variable that exhibits a significant effect is the crisis dummy variable. This result is in line with a result supporting the limited role of household credit risk on the mortgage rate and suggests that banks treated borrowers equally in terms of the interest rate charged during the crisis period as it was increased for all the households consistent with Hypothesis 3. The average borrowing spread increased by $1.26 \%$ during the crisis period, ceteris paribus. Nevertheless, there 
was an exception since those customers that could offer profitable opportunities for the bank obtained funding at a lower rate.

Although the risk of the clients does not exhibit a significant effect on the borrowing rate, it is very relevant for the bank decision of whether or not to grant the mortgage. Moreover, the lack of significance of household idiosyncratic risk could be explained by the role played by the aggregate level of risk that is common to all households and that leads to a strong increase of borrowing rates during the crisis period.

< Insert Table 4 here >

\section{Robustness tests}

\subsection{Alternative specifications of income and wealth constraints}

The maximum loan-to-value (LTV) ratio in our analysis is set at 0.8. Nevertheless, in the pre-crisis period mortgages had LTV ratios higher than 0.8 , which are consistent with higher debt capacity and less financial constraints on households. Along the same lines, the threshold of $33 \%$ imposed on mortgage payments relative to income could also be a different percentage for some households. In the interest of confirming the robustness of our results with regard to alternative thresholds for the definition of the financial constraints, we check the robustness of our results when we use an LTV equal to 0.7 and 0.9 and mortgage payment to income thresholds equal to 0.25 and $0.4 .^{7}$ Results are reported in Table 5.

Column 1 contains the results of the baseline analysis reported in the interest of comparability. Columns (2) and (3) contain the results obtained for an alternative

\footnotetext{
${ }^{7}$ Note that the use of LTV equal to or greater than $100 \%$ implies that the wealth constraint cannot be used in our analysis.
} 
definition of the financial constraints for which we use a loan-to-value equal to 0.7 and 0.9 , respectively. Although the magnitude of the constraint coefficients changes slightly, both income constraints remain non-significant. The effects of the remaining variables remain invariant with respect to those obtained in the baseline specification. Columns (4) and (5) report the results obtained for an alternative definition of the income constraint, for which we use thresholds 0.25 and 0.4 , respectively, as the mortgage payment to income. The results obtained for the two alternative income constraint specifications are very similar those ones observed in Column (1), confirming the limited effect of income constraint on the mortgage rates.

\section{$<$ Insert Table 5 here >}

\subsection{Dealing with the endogeneity of income and wealth}

In this subsection we deal with the potential endogeneity of income and wealth. Permanent income could be more important than current income to explain the tenure choice and housing consumption as both decisions are taken in the long term. For this reason -and to avoid any potential source of endogeneity- we use an exogenous proxy for permanent income. As shown by Haurin et al. (1997), the use of permanent income may overcome potential problems of endogeneity given that it is a predicted value and not an observed one. Haurin et al. (1997) derive the permanent income by estimating predicted values based on a regression of the income on exogenous explanatory variables such as age, education, gender, race/ethnicity, and health. The endogeneity of the income is also suggested by Bourassa (2000) who also uses permanent income to calculate the borrowing constraint gap for New Zealander households. Bourassa (2000) excludes the age and marital status from the set of variables to predict permanent income and, instead, uses education and location related variables. The exclusion of age and marital status is 
due to the fact that they could introduce or exacerbate problems of collinearity in the tenure choice equation.

In our attempt to predict permanent income for each wave in the survey to deal with the potential endogeneity of household income, we regress the income on several characteristics related to the head of family, such as gender, health, and educational levels, and dummy variables indicating the sector in which she/he works (primary, secondary, or tertiary) We also control by the number of people dwelling in the house. Results on the drivers of the mortgage spread obtained using permanent income instead of income are reported in Column (1) of Table 6. The results obtained are consistent with the ones obtained in the baseline regressions and suggest that our results are not affected by the potential endogeneity of income.

In addition, and to show that our results are not affected by the potential endogeneity of wealth, we use the predicted wealth to estimate the desired housing value and to calculate borrowing constraints. In particular, we follow Duca and Rosenthal (1993, 1994a) and Bourassa (2000) and regress net wealth on all of the exogenous variables in the model as well as some additional variables. We regress net wealth on the exogenous variables employed in the previous analyses: education, gender, dummy indicating whether the household lives in an urban or rural area, number of household members, and the number of those members that are employed. We also use the following additional variables that are not defined in the Appendix: (i) a dummy that equals one if the household has art or antiques, and zero otherwise; (ii) number of years that the head of the family has been working at their current employer; (iii) a dummy that equals one if the household has used a mortgage loan to finance services or goods other than real estate, and zero otherwise; (iv) a dummy that equals one if the household has had problems making loan payments in the last year, and zero otherwise; (v) a dummy that 
equals one if the household has a checking account, and zero otherwise; and (vi) a dummy that equals one if the household has received an inheritance, and zero otherwise.

Column (2) of Table 6 reports the results obtained when we deal with the potential endogeneity of both income and wealth. The results are fully consistent with the baseline analysis and suggest that the potential endogeneity of either income or wealth does not affect our results.

\section{< Insert Table 6 here >}

\subsection{Dealing with selection bias}

For this purpose, we use a Heckman (1979) two-step econometric technique to control using the sample selection bias originated in the decision on whether or not to finance the home purchase using a loan. This methodology consists of two steps. The first step is devoted to modelling the likelihood of financing the home purchase through a loan, whereas the second stage determines the drivers of the loan characteristics by correcting selection bias given the estimates from the first stage.

The Heckman selection model assumes an underlying regression relationship:

$$
r_{i}=\delta^{\prime} X_{i}+\varepsilon_{1 i}
$$

where $r_{i}$ denotes the mortgage interest rate in excess of 1-year Euribor, and $X_{i}$ is a vector of variables affecting the mortgage rate, including a measure of the household risk scoring; a variable indicating whether the household is profitable for the bank in view of its use of banking resources; the orthogonalized wealth and income constraints; a dummy variable indicating whether the household has other types of debt besides the mortgage; and the age and labor situation of the person of reference. Furthermore, we use dummy 
variables indicating the year the home was purchased in order to control using the specific characteristics of each year.

Nevertheless the dependent variable for household $i$ is only observed if the household has a mortgage. This is determined from a selection equation such that $r_{i}$ is observed if:

$$
\gamma Z_{i}+\varepsilon_{2 i}>0
$$

where $\varepsilon_{1 i} \sim N(0, \sigma), \varepsilon_{2 i} \sim N(0,1)$, and $\operatorname{corr}\left(\varepsilon_{1 i}, \varepsilon_{2 i}\right)=\rho$. Moreover, $Z_{i j}$ includes the same variables in $X_{i}$ plus the number of members employed and living in the home as an additional measure that could determine whether the household uses a mortgage to finance the housing purchase.

The total number of households employed in this analysis consists of 1,409 households, of which 722 are censored (coinciding with those households that are renters and those that did not use a loan to purchase their home). However, the estimated coefficient for the inverse Mills ratio (the lambdas) is not significantly different from zero, confirming that there is no sample selection bias due solely to the use of homeowners with mortgage in the baseline analysis. Thus, there is no selection bias originated in the decision on whether or not to finance the home purchase using a loan and so even controlling for it the results remain unchanged.

\section{Conclusions}

Previous literature shows that riskier borrowers pay higher interest rates. However, it is inconclusive with regard to the impact that different factors related to household risk may have on the mortgage rate. Moreover, the effect of household risk profiles on mortgage rates has traditionally been measured by means of credit scoring or risk indicators, 
meaning that important dimensions of the constraints (home affordability) are not subject to control. Our paper adds evidence to this discussion by analyzing the effect that credit risk, income and wealth constraints, previous debts, and certain characteristics that may help credit institutions to identify clients as profitable customers have on mortgage rates.

Our data comes from the Spanish Household Finance Survey in four different years: 2002, 2005, 2008, and 2011. The Spanish case is a particularly interesting one as the country experienced a large housing bubble in the years prior to the crisis that burst during the last period of our sample. In this sense, our methodology and data allow us to identify the impact of financing constraints and credit scoring on the mortgage lending policy before and during the crisis.

Our results suggest that "profitable customers" -in terms of the future fees that the credit institutions may charge them- are able to bargain for lower mortgage rates. Nevertheless, household risk profiles do not affect the mortgage rates they are charged. In fact, credit institutions tend to charge higher rates during the crisis to all customers irrespective of their risk profiles or their degree of profitability. Overall, the results suggest that banks ignored household credit risk profiles when determining the interest rate charged. 


\section{References}

Agarwal, S., Chomsisengphet, S., Liu, C., and Souleles, N. S. (2010). Benefits of relationship banking: evidence from consumer credit markets. Working Paper Series: WP-2010-05. Federal Reserve Bank of Chicago.

Allen, J., Clark, C. R., and Houde, J. F. (2014). Price dispersion in mortgage markets. The Journal of Industrial Economics, 62, 377-416.

Ampudia, M., and Mayordomo, S. (2015). Borrowing constraints and housing price expectations in the Euro area. Available at SSRN: http://ssrn.com/abstract=2657176

Barakova, I., Bostic, R.W., Calem, P.S., and Wachter, S.M. (2003). Does credit quality matter for homeownership?. Journal of Housing Economics, 12, 318-336.

Barakova, I., Calem, P. S., and Wachter, S. M. (2014). Borrowing constraints during the housing bubble. Journal of Housing Economics, 24, 4-20.

Beck, T., Büyükkarabacak, B., Rioja, F., and Valev, N. (2012). Who gets the credit? And does it matter? Household vs firm lending across countries. B.E. Journal of Macroeconomics 12.

Bourassa, S. C. (2000). Ethnicity, endogeneity, and housing tenure choice. Journal of Real Estate Finance and Economics, 20, 323-341.

Bourassa, S. C. and Hoesli, M. (2010). Why do the Swiss rent?. Journal of Real Estate Finance and Economics, 40, 286-309.

Brown, M., and Hoffmann, M. (2013). Mortgage relationships. Working Paper No. 1310 University of St. Gallen. 
Bucks B. K., Kennickell, A. B., Mach, T. L., and Moore, K. B. (2009). Changes in U.S. family finances from 2004 to 2007: Evidence from the Survey of Consumer Finances. Federal Reserve Bulletin (February), A1-A56.

Calem, P. S., Firestone, S., and Wachter, S. M. (2010). Credit impairment and housing tenure status. Journal of Housing Economics, 19, 219-232.

Chiang, R. C., Chow Y. F., and Liu, M. (2002). Residential mortgage lending and borrower risk: The relationship between mortgage spreads and individual characteristics. The Journal of Real Estate Finance and Economics, 25, 5-32.

Crespi, R., García-Cestona, M. A., and Salas, V. (2004). Governance mechanisms in Spanish banks. Does ownership matter?. Journal of Banking and Finance, 28, 2311-2330.

Diaz-Serrano, L. (2005). On the negative relationship between labor income uncertainty and homeownership: Risk-aversion vs. credit constraints. Journal of Housing Economics, 14, 109-126.

Duca, J. V., and Rosenthal S. S. (1993). Borrowing constraints, household debt, and racial discrimination in loan markets. Journal of Financial Intermediation, 3, 77-103.

Duca, J. V., and Rosenthal, S. S. (1994a). Borrowing constraints and access to owneroccupied housing. Regional Science and Urban Economics, 24, 301-322.

Duca, J. V., and Rosenthal, S. S. (1994b). Do mortgage rates vary based on household default characteristics? Evidence on rate sorting and credit rationing. The Journal of Real Estate Finance and Economics, 8, 99-113. 
Edelberg, W. (2006). Risk-based pricing of interest rates for consumer loans. Journal of Monetary Economics, 53, 2283-2298.

Einav, L., Jenkins, M., and Levin, J. (2013). The impact of credit scoring on consumer lending. The RAND Journal of Economics, 44, 249-274.

European Central Bank (2013). The Euro system household finance and consumption survey: Results from the first wave. Statistics Paper Series No. 2.

Haurin, D.R., Hendershott, P.H., and Wachter, S.M. (1996). Wealth accumulation and housing choices of young households: an exploratory investigation. Journal of Housing Research, 7, 33-57.

Haurin, D.R., Hendershott, P.H., and Wachter, S.M., (1997). Borrowing constraints and the tenure choice of young households. Journal of Housing Research, 8, 137-154.

Holmes, J., Isham, J., Petersen, R., and Sommers, P. M. (2007). Does relationship lending still matter in the consumer banking sector? Evidence from the automobile loan market. Social Science Quarterly, 88, 585-597

Keys, B.J., Mukherjee, T., Seru, A., and Vig, V. (2010). Did securitization lead to lax screening? Evidence from subprime loans. The Quarterly Journal of Economics, $125,307-362$.

Lago-González, R., and Salas-Fumás, V. (2005), Market power and bank interest rate adjustments, Bank of Spain Working Paper no. 0539.

Linneman, P., Megbolugbe, I. F., Wachter, S., and Cho, M. (1997). Do borrowing constraints change U.S. homeownership rates?. Journal of Housing Economics, 6, $318-333$ 
Linneman, P. and Wachter, S. (1989). The impacts of borrowing constraints on homeownership. The Journal of the American Real Estate and Urban Economics Association, 17, 389-402.

Magri, S., and Pico, R. (2011). The rise of risk-based pricing of mortgage interest rates in Italy. Journal of Banking and Finance, 35, 1277-1290.

Maudos, J., Pastor, J. M., and Pérez, F. (2002). Competition and efficiency in the Spanish banking sector: The importance of specialization. Applied Financial Economics, $12,505-516$.

Puri, M., Rocholl, J., and Steffen, S. (2011). Global retail lending in the aftermath of the US financial crisis: Distinguishing between supply and demand effects. Journal of Financial Economic, 100, 556-578.

Rosenthal, S.S., 2002. Eliminating credit barriers: how far can we go? In: Retsinas, N.P. (Ed.), Low-income Homeownership: Examining the Unexamined Goal.

Rubin, D. B., 1987. Multiple Imputation for Nonresponse in Surveys, Wiley, New York.

Tsai, M. S., Liao, S. Z., and Chiang, S. L. (2009). Analyzing yield, duration and convexity of mortgage loans under prepayment and default risks. Journal of Housing Economics, 18, 92-103.

Van Leuvensteijn, M., Bikker, J.A., van Rixtel, A., and Kok Sørensen, C. (2011). A new approach to measuring competition in the loan markets of the Euro area. Applied Economics, 43, 3155-3167. 


\section{Appendix. Definition of variables}

The control variables used in our analysis are created as follows:

\section{a. Household income}

The EFF provides the household income in the year of survey. To obtain the desired home value we need the household income for the year in which the home was purchased. We obtain the income for that year by discounting the income by the inflation. This is equivalent to assuming that the income increases at the same rate as inflation does.

\section{b. Household net and gross wealth}

The household gross wealth is obtained as the sum of the value of financial assets (listed and non-listed stocks, mutual funds, pension funds, life insurance, bank time deposits and other financial assets) and real assets (principal residence, other real estate properties, jewelry, art, and own business, in the event that they run a business) held by the household. The net wealth is defined as the total wealth minus the household's total debt.

To obtain the desired home value we use the net wealth in the year in which the household purchased the home. This is calculated as the gross wealth minus the change in the housing value and the total savings over the period spanning from the home purchase date to the survey date.

\section{c. Other household characteristics}

Among the household characteristics affecting the desired home value or the mortgage rates: 
- Education: three dummy variables indicating whether the highest level of education of the person of reference is obtained at primary school, high school, or university.

- $\quad$ Age of the person of reference and age-squared.

- Number of family members.

- Number of adults working.

- Rural/urban area: dummy variables constructed on the basis of the economic sector in which the activities of the person of reference take place: primary, secondary, or tertiary sector, under the assumption that those households in which the person of reference works in the primary (secondary or tertiary) sector live in a rural (urban) area.

- Gender: dummy variables for the gender of the person of reference.

- Year of move: dummy variables indicating the year in which the household purchased/rented their current home.

- Marital status: four dummy variables indicating whether the person of reference is single, married or in a consensual union with legal basis, widowed, or divorced.

- Labor situation: four dummy variables indicating whether the person of reference is employed, self-employed, retired, or unemployed.

All the previous variables are employed to obtain the desired housing value, where the variables are defined in terms of the year in which the household purchased the home. We impute the value of the variables at the purchase year as follows. The education, number of family members, number of working adults, rural or urban area proxy, gender, marital status and labor situation are assumed to remain unchanged between the year in which the home is purchased and the survey date. This imputation method seems reasonable given that the maximum distance between the two events is 3 years. Given 
that the survey contains the year of birth of the person of reference, we can easily calculate his/her age at the year of purchase.

\section{d. Credit Scoring}

The survey does not contain information on the credit scoring. We propose a simple measure of this scoring following the advice of financial institutions on the dimensions and practices considered to define this scoring and the set of variables proposed in the access-to-mortgage guide elaborated by the Central Bank of Spain to define the credit history. ${ }^{8}$ This measure of scoring is adapted to the variables contained in the EFF. Our aim is to create a credit scoring indicator on the basis of the main information used by banks to evaluate the process of mortgage granting. The scoring is a weighted average of three dimensions that refer to the household capacity for payment (with the weights shown in brackets): (i) payment and capital capacity (50\%), (ii) household characteristics and payment history (30\%), and (iii) characteristics of other household debts (20\%). Each category consists of several subcategories with different weights and scores as follows:

- Payment and capital capacity (50\%):

- Ratio of liquid assets to income: LI (50\%)

- $\quad$ If $\mathrm{LI}>0.75$ then scoring $=25$.

- $\quad$ If $\mathrm{LI}>0.5$ and $\mathrm{LI} \leqslant 0.75$ then scoring $=18.75$.

- $\quad$ If $L I>0.25$ and $L I \leqslant 0.5$ then scoring $=12.5$.

- $\quad$ If $\mathrm{LI} \leqslant 0.25$ then scoring $=6.25$.

- Ratio of total debt relative to labor income: DL (30\%)

- If $\mathrm{DL}<2$ then scoring $=15$.

\footnotetext{
${ }^{8}$ See "Guía de Acceso al Préstamo Hipotecario" (Bank of Spain): http://www.bde.es/bde/es/secciones/informes/Folletos/guia_de_acceso_a/
} 
- $\quad$ If $\mathrm{DL} \geqslant 2$ and $\mathrm{DL}<4$ then scoring $=11.25$.

- $\quad$ If $\mathrm{DL} \geqslant 4$ and $\mathrm{DL}<6$ then scoring $=7.5$.

- $\quad$ If $\mathrm{DL} \geqslant 6$ then scoring $=3.75$.

- Ratio of total debt relative to total gross wealth: DW (20\%)

- $\quad$ If $\mathrm{DW} \leqslant 0.25$ then scoring $=10$.

- $\quad$ If $\mathrm{DW}>0.25$ and $\mathrm{DW} \leqslant 0.5$ then scoring $=7.5$.

- $\quad$ If DW $>0.5$ and DW $\leqslant 0.75$ then scoring $=5$.

- $\quad$ If $\mathrm{DW}>0.75$ then scoring $=2.5$.

- Household characteristics (30\%):

- The person of reference in the household is married or in a domestic partnership (15\%)

- If yes then scoring $=4.5$, otherwise scoring $=0$.

- The household has other real assets that could be used as guarantee $(15 \%)$

- If yes then scoring $=4.5$, otherwise scoring $=0$.

- There is a civil servant among the household members (35\%)

- If yes then scoring $=10.5$, otherwise scoring $=0$.

- At least two people living in the household are employed (35\%)

- If yes then scoring $=10.5$, otherwise scoring $=0$.

- Characteristics of other household debts (20\%):

- Time-to-maturity of the mortgage: TM (70\%)

- If $\mathrm{TM}>20$ then scoring $=14$.

- $\quad$ If $\mathrm{TM} \geqslant 10$ and $\mathrm{TM}<20$ then scoring $=10.5$.

- $\quad$ If $\mathrm{TM} \geqslant 5$ and $\mathrm{TM}<10$ then scoring $=5.25$.

- $\quad$ If $\mathrm{TM}<5$ then scoring $=1.3124$. 
- The household uses several loans for the house purchase (30\%)

- If yes then scoring $=6$, otherwise scoring $=0$.

The scoring indicator is defined such that the higher the scoring obtained, the greater the risk. The measure is between 0 (lowest risk) and 100 (highest risk).

\section{e. Customer profitability}

We consider two categories depending on the banking business to which they refer in order to define profitable customers: fee-oriented activities or asset management activities. Fee-oriented activities are: (i) the use of credit cards, (ii) use of electronic payments, (iii) use of checks, (iv) use of direct billing or direct deposits, and (v) use of telephone and internet banking. Asset management activities include: (a) holdings of mutual funds, (b) holdings of life insurance, and (c) holdings of pension funds. For each of the eight total categories referring to the use of a given service or the holding of a given asset, we define a dummy variable that takes on a value of 1 in cases where the household uses the corresponding service or holds the corresponding asset, and a value of 0 otherwise. To define the variable referred to total profitability, we total the values obtained for the 8 dummy categories so that a household that uses all services and holds all three types of assets will be assigned a value of 8 , whereas the minimum value that can be obtained is zero. We later distinguish the degree of profitability in relation to feeoriented activities by totaling the values of the five dummy variables (i) to (v), so that the resulting variable value ranges between 0 and 5. Finally, in order to obtain the degree of profitability in relation to asset management activities, we total the values of the three dummy variables (a) to (c) so that the resulting variable value ranges between 0 and 3 . 


\section{Table 1: Descriptive statistics}

Panel A of Table 1 contains the descriptive statistics (mean, median, and standard deviation) of a series of variables referred to the housing, the financial situation and several demographic characteristics of households that purchased homes close to the four survey dates employed in our analysis $(2002,2005,2008$, and 2011). These are used to estimate the desired home value of the households. Panel B contains the descriptive statistics of the variables employed to study the determinants of mortgage spreads (degree of financial constraints, customer profitability, risk profile, and demographic characteristics) based on a sample that consists of recent home buyers that used a mortgage to finance the house purchase.

\section{Panel A}

\begin{tabular}{|c|c|c|c|}
\hline Variables & Mean & Median & SD \\
\hline Housing price of purchase & 201,056 & 137,893 & 232,343 \\
\hline Annual income before housing purchase & 50,571 & 31,376 & 63,227 \\
\hline Gross wealth before housing purchase & 453,364 & 73,951 & $1,702,729$ \\
\hline Age & 39.26 & 38.00 & 9.50 \\
\hline Marital status: Single & 0.19 & 0.00 & . \\
\hline Marital status: Married or consensual union & 0.71 & 1.00 & . \\
\hline Marital status: Widowed & 0.02 & 0.00 & . \\
\hline Marital status: Divorced & 0.09 & 0.00 & . \\
\hline Education: Primary & 0.32 & 0.00 & . \\
\hline Education: Secondary & 0.34 & 0.00 & . \\
\hline Education: Tertiary & 0.34 & 0.00 & . \\
\hline Number of people dwelling in the home & 2.85 & 3.00 & 1.27 \\
\hline Number of people with job dwelling in the home & 1.57 & 2.00 & 0.68 \\
\hline Gender $(1=$ Male $0=$ Female $)$ & 0.62 & 1.00 & . \\
\hline Labor situation: Employee & 0.66 & 1.00 & . \\
\hline Labor situation: Self-employed & 0.16 & 0.00 & . \\
\hline Labor situation: Unemployed & 0.02 & 0.00 & . \\
\hline Labor situation: Retired & 0.19 & 0.00 & . \\
\hline Housing is in a urban area $(1=$ Yes $0=$ No $)$ & 0.89 & 1.00 & . \\
\hline \% Households buying housing 1999 & 11.61 & 0.00 & . \\
\hline$\%$ Households buying housing 2000 & 7.52 & 0.00 & . \\
\hline$\%$ Households buying housing 2001 & 4.28 & 0.00 & . \\
\hline$\%$ Households buying housing 2002 & 12.52 & 0.00 & . \\
\hline \% Households buying housing 2003 & 10.76 & 0.00 & . \\
\hline \% Households buying housing 2004 & 6.76 & 0.00 & . \\
\hline$\%$ Households buying housing 2005 & 13.93 & 0.00 & . \\
\hline \% Households buying housing 2006 & 8.70 & 0.00 & . \\
\hline \% Households buying housing 2007 & 6.06 & 0.00 & .. \\
\hline$\%$ Households buying housing 2008 & 6.85 & 0.00 & . \\
\hline \% Households buying housing 2009 & 5.09 & 0.00 & . \\
\hline$\%$ Households buying housing 2010 & 4.28 & 0.00 & . \\
\hline \% Households buying housing 2011 & 1.64 & 0.00 & . \\
\hline Number of observations & 864 & & \\
\hline
\end{tabular}




\section{Panel B}

\begin{tabular}{l|ccc} 
Variables & Mean & Median & SD \\
\hline Mortgage rate spread (over 1-year Euribor) & 1.18 & 1.06 & 1.24 \\
Degree of income constraint & 0.38 & 0.32 & 0.26 \\
Degree of wealth constraint & 0.79 & 0.24 & 4.39 \\
Customer profitability (all activities) & 2.99 & 3.00 & 1.35 \\
Customer profitability (fee oriented activities) & 2.52 & 2.00 & 0.97 \\
Customer profitability (asset management activities) & 0.47 & 0.00 & 0.65 \\
Risk scoring & 39.74 & 39.00 & 15.33 \\
Debt other than mortgage (Yes=1) & 0.38 & 0.00 &. \\
Age & 38.90 & 38.00 & 8.52 \\
Number of people dwelling in the home & 2.96 & 3.00 & 1.25 \\
Labor situation: Employee & 0.69 & 1.00 &. \\
Labor situation: Self-employed & 0.17 & 0.00 &. \\
Labor situation: Unemployed & 0.01 & 0.00 &. \\
Labor situation: Retired & 0.16 & 0.00 &. \\
\% Households moving at 1999 & 12.19 & 0.00 &. \\
\% Households moving at 2000 & 5.81 & 0.00 &. \\
\% Households moving at 2001 & 4.08 & 0.00 &. \\
\% Households moving at 2002 & 13.21 & 0.00 &. \\
\% Households moving at 2003 & 11.99 & 0.00 &. \\
\% Households moving at 2004 & 7.05 & 0.00 &. \\
\% Households moving at 2006 & 19.30 & 0.00 &. \\
\% Households moving at 2007 & 8.84 & 0.00 &. \\
\% Households moving at 2008 & 5.39 & 0.00 &. \\
\% Households moving at 2010 & 3.38 & 0.00 &. \\
\% Households moving at 2011 & 4.31 & 0.00 &. \\
Number of observations & 3.19 & 0.00 &. \\
\hline & 1.28 & 0.00 &. \\
\hline & 636 & & \\
\hline
\end{tabular}




\section{Table 2: Estimation of desired housing value}

This table contains the coefficients obtained from the estimation of desired housing value using a sample that consists of recent buyers over the period spanning the three years prior to the survey date, as explained in Section 2.1. The results are obtained on the basis of a censored model that uses the logarithm of the purchase price as the desired home value for those households that are not constrained in income or wealth, and the minimum of the logarithm of home value compatible with not being constrained for those constrained households as the dependent variable. Besides the variables referred to the housing and household financial and demographic characteristics, we use year of purchase fixed effects and the estimation is robust to heteroskedasticity. Standard errors are reported between brackets. $* * *, * *$, and $*$ denote statistical significance at $10 \%, 5 \%$, and $1 \%$ level, respectively.

Dependent variable: Housing purchase price

Annual income before housing purchase

Gross wealth before housing purchase

Age

Squared of age

Marital status: Married or consensual union

Marital status: Widowed

Marital status: Divorced

Education: Secondary

Education: Tertiary

Number of people dwelling in the home

Number of people with job dwelling in the home

Gender $(1=$ Male $0=$ Female $)$

Labor situation: Self-employed

Labor situation: Retired

Labor situation: Unemployed or Non-active

Housing is in a urban area $(1=$ Yes $0=$ No $)$
Coefficient

$0.368 * * *$

(0.04)

$0.010 *$

$(0.01)$

0.008

$(0.03)$

0.000

$(0.00)$

0.103

(0.09)

0.155

(0.21)

0.010

$(0.12)$

$0.272 * * *$

(0.07)

$0.404 * * *$

(0.08)

0.032

(0.03)

$-0.132 * *$

(0.05)

$-0.036$

(0.06)

0.102

(0.08)

$-0.624 * * *$

$(0.22)$

0.026

(0.08)

$0.311 * * *$

(0.10)

Year Fixed-Effects

Yes

864

175

Censored Observations

0.16 
Table 3: The role of households' risk profiles and characteristics on mortgage rates

This table contains the results that aim to understand the effect of a series of variables affecting mortgage rates. To this end, we regress the mortgage interest rate in excess of 1-year Euribor (mortgage spread) on a series of explanatory variables. These variables include those affecting the mortgage rate, including a measure of household risk scoring; a variable indicating whether the household is profitable for the bank in view of its use of banking resources; wealth and income constraints; a dummy variable indicating whether the household has other types of debt besides the mortgage; and the age and labor situation of the person of reference. We furthermore use dummy variables indicating the year the home was purchased in order to control using the specific characteristics of each year. Column (1) refers to the case in which the variable indicating whether the household is profitable for the bank, in view of its use of banking resources, is defined considering both fee-oriented and asset management activities. The results contained in column (2) correspond to the case in which the variable indicating household profitability is defined using fee-oriented activities and asset management activities. Standard errors are reported between brackets. $* * * * *$, and $*$ denote statistical significance at $10 \%, 5 \%$, and $1 \%$ level, respectively.

Dependent variable: Mortgage spread

(1)

(2)

\begin{tabular}{lcc}
\hline Client profitability & $\begin{array}{c}-0.113^{* * *} \\
(0.04)\end{array}$ \\
Client profitability (fee-oriented) & & $-0.147 * * *$ \\
& & $(0.05)$ \\
Client profitability (asset management) & & -0.049 \\
& & $(0.04)$ \\
Risk scoring & 0.000 & 0.001 \\
& $(0.00)$ & $(0.00)$ \\
Degree of income constraint & -0.245 & -0.251 \\
& $(0.18)$ & $(0.18)$ \\
Degree of wealth constraint & 0.005 & 0.0048 \\
& $(0.01)$ & $(0.01)$ \\
Debt other than mortgage (Yes=1) & 0.084 & 0.086 \\
Age & $(0.06)$ & $(0.06)$ \\
& 0.006 & 0.005 \\
Labor situation: Self-employed & $(0.01)$ & $(0.01)$ \\
& 0.051 & 0.053 \\
Labor situation: Retired & $(0.08)$ & $(0.08)$ \\
& 1.104 & 1.118 \\
Labor situation: Unemployed or Non-active & $(0.69)$ & $(0.68)$ \\
& $0.370 * * *$ & $0.369 * * *$ \\
Year Fixed-Effects & $(0.15)$ & $(0.15)$ \\
Number of Observations & Yes & Yes \\
R-squared & 636 & 636 \\
& 0.278 & 0.278 \\
\hline
\end{tabular}




\section{Table 4: The role of households' risk profiles and characteristics on mortgage rates. The effect of the crisis}

This table contains results aimed at providing an understanding of the effect of a series of variables affecting mortgage rates. To this end, we regress the mortgage interest rate in excess of 1-year Euribor (mortgage spread) demeaned each year, depending on the year in which the housing was purchased, on a series of explanatory variables. These variables include those affecting the mortgage rate, including a measure of household risk scoring; a variable indicating whether the household is profitable for the bank in view of its use of banking resources; wealth and income constraints; a dummy variable indicating whether the household has other types of debt besides the mortgage; a crisis dummy variable that takes on a value of 1 from 2009; and the interaction of the crisis dummy variable with the five aforementioned variables. We furthermore use the age and labor situation of the person of reference. Standard errors are reported between brackets. ***, $* *$, and $*$ denote statistical significance at $10 \%, 5 \%$, and $1 \%$ level, respectively.

\begin{tabular}{l|cc} 
Dependent variable: Demeaned mortgage spread & Coefficient & Std. Error \\
\hline Customer profitability & $-0.104^{* * *}$ & $(0.03)$ \\
Risk scoring & 0.002 & $(0.00)$ \\
Degree of income constraint & -0.194 & $(0.15)$ \\
Degree of wealth constraint & 0.005 & $(0.01)$ \\
Debt other than mortgage (Yes=1) & 0.077 & $(0.10)$ \\
Customer profitability x Crisis & -0.138 & $(0.11)$ \\
Risk scoring x Crisis & -0.046 & $(0.04)$ \\
Degree of income constraint x Crisis & 0.058 & $(0.38)$ \\
Degree of wealth constraint x Crisis & -0.144 & $(0.17)$ \\
Other debt besides the mortgage (Yes=1) x Crisis & -0.029 & $(0.29)$ \\
Crisis & $1.258^{*}$ & $(0.67)$ \\
Age & 0.006 & $(0.01)$ \\
Labor situation: Self-employed & 0.056 & $(0.11)$ \\
Labor situation: Retired & 1.063 & $(1.12)$ \\
Labor situation: Unemployed or Inactive & $0.362 * * *$ & $(0.14)$ \\
Constant & -0.082 & $(0.30)$ \\
\hline Number of Observations & 636 & \\
R-squared & 0.06 & \\
\hline
\end{tabular}


Table 5: The role of households' risk profiles and characteristics on mortgage rates. Alternative financial constraints

This table contains results aimed at providing an understanding of the effect of a series of variables affecting mortgage rates using alternative definitions of financial constraints. To this end, we regress the mortgage interest rate in excess of 1-year Euribor (mortgage spread) on a series of explanatory variables. These variables include those affecting the mortgage rate, including a measure of household risk scoring; a variable indicating whether the household is profitable for the bank in view of its use of banking resources; wealth and income constraint; and a dummy variable indicating whether the household has other types of debt besides the mortgage. We furthermore use the age and labor situation of the person of reference and dummy variables indicating the year the home was purchased in order to control using the specific characteristics of each year. Column (1) contains the results of the baseline analysis that are reported in the interest of comparability. Columns (2) and (3) contain the results obtained for an alternative definition of the financial constraints for which we use a loan-to-value equal to 0.7 and 0.9 , respectively. Columns (4) and (5) report the results obtained for an alternative definition of the income constraint for which we use as the mortgage payment to income thresholds 0.25 and 0.4 , respectively. Standard errors are reported between brackets. ***, **, and * denote statistical significance at $10 \%, 5 \%$, and $1 \%$ level, respectively.

\begin{tabular}{lccccc} 
Dependent variable: Mortgage spread & $(1)$ & $(2)$ & $(3)$ & $(4)$ & $(5)$ \\
\hline Client profitability & $-0.113^{* * *}$ & $-0.114^{* * *}$ & $-0.113^{* * *}$ & $-0.114 * * *$ & $-0.113^{* * *}$ \\
Risk scoring & $(0.04)$ & $(0.04)$ & $(0.04)$ & $(0.04)$ & $(0.04)$ \\
& 0.000 & 0.000 & 0.000 & 0.000 & 0.000 \\
Degree of income constraint & $(0.00)$ & $(0.00)$ & $(0.00)$ & $(0.00)$ & $(0.00)$ \\
& -0.245 & -0.295 & -0.207 & -0.166 & -0.310 \\
Degree of wealth constraint & $(0.18)$ & $(0.21)$ & $(0.15)$ & $(0.11)$ & $(0.23)$ \\
& 0.005 & 0.003 & 0.0098 & 0.004 & 0.0048 \\
Debt other than mortgage (Yes=1) & $(0.01)$ & $(0.00)$ & $(0.01)$ & $(0.01)$ & $(0.01)$ \\
& 0.084 & 0.084 & 0.085 & 0.083 & 0.085 \\
Age & $(0.06)$ & $(0.06)$ & $(0.06)$ & $(0.06)$ & $(0.06)$ \\
& 0.006 & 0.006 & 0.007 & 0.006 & 0.006 \\
Labor situation: Self-employed & $(0.01)$ & $(0.01)$ & $(0.01)$ & $(0.01)$ & $(0.01)$ \\
& 0.051 & 0.049 & 0.053 & 0.055 & 0.051 \\
Labor situation: Retired & $(0.08)$ & $(0.08)$ & $(0.08)$ & $(0.08)$ & $(0.08)$ \\
& 1.104 & 1.101 & 1.104 & 1.102 & 1.102 \\
Labor situation: Unemployed or Non-active & $0.370^{* * *}$ & $0.371 * * *$ & $0.368 * * *$ & $0.366 * * *$ & $0.371 * * *$ \\
& $(0.15)$ & $(0.15)$ & $(0.15)$ & $(0.15)$ & $(0.15)$ \\
\hline Year Fixed-Effects & Yes & Yes & Yes & Yes & Yes \\
Number of Observations & 636 & 636 & 636 & 636 & 636 \\
R-squared & 0.278 & 0.278 & 0.278 & 0.278 & 0.278 \\
\hline
\end{tabular}




\section{Table 6: The role of households' risk profiles and characteristics on mortgage rates. Use of permanent income and predicted wealth}

This table contains results aimed at providing an understanding of the effect of a series of variables affecting mortgage rates. The novelty in Column (1) of Table 6 with respect to the baseline analysis in column (1) of Table 3 is that instead of using household income to obtain the desired housing value and to define the income constraint, we use the permanent income. Permanent income is predicted based on regressing the income on exogenous explanatory variables such as age, education, gender, race/ethnicity, and health. Results in Column (2) of this table are obtained using permanent income and predicted net wealth instead of household income and net wealth to obtain the desired housing value and to define income and wealth constraints. As permanent income, predicted net wealth is obtained regressing net wealth on a series of exogenous variables. Standard errors are reported between brackets. $* * *, * *$, and $*$ denote statistical significance at $10 \%, 5 \%$, and $1 \%$ level, respectively.

\begin{tabular}{lcc} 
Dependent variable: Mortgage spread & $(1)$ & $(2)$ \\
\hline Client profitability & $-0.110^{* * *}$ & $-0.097 * *$ \\
Risk scoring & $(0.04)$ & $(0.05)$ \\
& 0.001 & 0.000 \\
Degree of income constraint & $(0.00)$ & $(0.00)$ \\
& -0.359 & -0.031 \\
Degree of wealth constraint & $(0.55)$ & $(0.03)$ \\
& 0.004 & 0.001 \\
Debt other than mortgage (Yes=1) & $(0.01)$ & $(0.00)$ \\
& 0.094 & 0.077 \\
Age & $(0.06)$ & $(0.06)$ \\
& 0.007 & 0.007 \\
Labor situation: Self-employed & $(0.01)$ & $(0.01)$ \\
& 0.079 & 0.030 \\
Labor situation: Retired & $(0.09)$ & $(0.10)$ \\
& 1.101 & 1.073 \\
Labor situation: Unemployed or Non-active & $(0.70)$ & $(0.68)$ \\
& $0.352^{* * *}$ & $0.335^{* *}$ \\
Year Fixed-Effects & $(0.14)$ & $(0.15)$ \\
Number of Observations & Yes & Yes \\
R-squared & 636 & 636 \\
\end{tabular}

